\title{
Takım Sporcularının Mobbing İle İlgili Görüşleri: Nitel Bir Araştırma
}

\author{
Emine KAYA*1, Zeynep ONAĞ ${ }^{2}$ \\ ${ }^{1}$ Manisa Celal Bayar Üniversitesi, Spor Bilimleri Fakültesi. https://orcid.org/0000-0001-9329-6960 \\ ${ }^{2}$ Manisa Celal Bayar Üniversitesi, Spor Bilimleri Fakültesi https://orcid.org/0000-0002-4034-6773
}

Orijinal Makale

Gönderi Tarihi: 27.08.2020

Kabul Tarihi: 05.12.2020

DOI: 10.30769/usbd.786441

Online Yayın Tarihi: 31.12.2020

\section{$\ddot{\mathbf{O z}}$}

$\mathrm{Bu}$ araştırmanın amacı, takım sporcularının mobbing ile ilgili görüşlerinin incelenmesidir. Araştırmada, nitel araştırma yöntemlerinden durum çalışması yöntemi, örneklem seçiminde ise, amaçlı örneklem yöntemlerinden kolay ulaşılabilir durum örneklemesi kullanılmıştır. Araştırmanın çalışma grubu, yaşları 18-28 arasında değişen takım sporu yapan 20 erkek takım sporcusundan oluşmaktadır. Veri toplama yöntemi olarak, nitel araştırma tekniklerinden yarı yapılandırılmış görüşme tekniği kullanılmıştır. Veri analizleri betimsel analiz yöntemi ile değerlendirilmiştir. Katılımcı görüşleri neticesinde elde edilen bulgular, spor ortamında en çok kimler mobinge maruz kalır, en çok kimler mobbing yapar ve sporcular açısından hangi davranışlar mobbing olarak kabul edilir şeklinde değerlendirilmiştir. Aynı zamanda "mobbinge maruz kalmanın nedenleri”, "mobingin sonuçları" ve "mobbing davranışlarının yaşanmaması için alınabilecek önlemler" olmak üzere 3 ana tema altında toplanmıştır. Mobinge maruz kalma temaları; örgütten kaynaklı, sosyal gruptan kaynaklı ve kişiden kaynaklı nedenler olmak üzere 3 ayrı alt temada incelenmiştir. Mobbingin sonuçları ise; maddi sonuçlar ve manevi sonuçlar olarak kategorize edilmiştir. Anahtar Kelimeler: Mobbing, Takım sporları, Sporda mobbing.

\section{Team Athletes' Opinions About Mobbing: A Qualitative Research}

\begin{abstract}
The aim of this research is to examine the opinions of team athletes about mobbing. In the research, case study method, one of the qualitative research methods, was used. In sample selection, easily accessible case sampling was used, which is one of the purposeful sampling methods. The study group of the study consisted of 20 male athletes aged between 18-28. As the data collection method, semi-structured interview technique, one of the qualitative research techniques, was used. The data analysis were evaluated with the descriptive analysis method and the findings were gathered under three main themes: "reasons for mobbing exposure", "consequences of mobing" and "measures to avoid mobbing behavior". Mobing exposure themes were examined in 3 sub-themes: organization-based, social-group-based and person-based causes. Consequences of mobbing were categorized as physical and moral consequences.
\end{abstract}

Keywords: Mobbing, Team sports, Mobbing in sports.

*Sorumlu Yazar: Emine KAYA, E-POSTA: emineky.10@gmail.com 


\section{GíRiş}

Mobbing (psikolojik taciz) kavramı, eskiden günümüze kadar uzanan örgütsel bir sorundur. İnsanlar örgüt ortamında sevmediği, kıskandığı, kendisinden daha iyi olan kişilere mobbing uyguladıkları gibi bazen de örgütteki kişinin modunu düşürmek, onu üzmek, psikolojisini bozmak ve performansını düşürmek için de mobing uygulamaktadırlar. Mobbingi uygulayan kişiler bunu kimi zaman çeşitli aşağılayıcı hareketler ve sözlerle kimi zaman da fiziksel hareketlerle yapılabilir. Psikolojik taciz kavramının ortaya çıkması için belli bir süreç gerekmektedir. Bu süreç için bazen tek bir tehdit, söz yeterli olurken bazen de aylar alan bir süreç olabilmektedir (Çobanoğlu, 2005). Aynı zamanda, mobbing eyleminde iki taraf bulunur. Mobbing yapan kişiye; saldırgan, tacizci, duygusal saldırgan, mobbing tacizcisi, zorba ve mobbing uygulayan kişi gibi isimler verilirken, mobbing saldırısına uğrayan kişiye ise mağdur, kurban, mobbing kurbanı/mağduru ve duygusal saldırıya uğrayan gibi ifadeler verilmektedir (Çobanoğlu, 2005; Tınaz, 2008).

Örgütlerde çoğu zaman var olan ancak çoğunlukla önemsenmeyen, konuşulmaktan çekinilen insan ilişkilerinden kaynaklanan sorunlar gözlenmektedir. Bu dile getirlmeyen sorunlar çalışanlar üzerinde stres yaratmaktadır. Rekabet koşullarına uyum sağlamaya çalışan örgütlerdeki bireylerde çatışmalar yaygınlaşmaktadır. $\mathrm{Bu}$ çatışmaların en büyük nedenlerinden biri, örgütlerdeki mobbing olaylarıdır (Özkalp ve Kırel, 2016).

Mobbing örgütlerde olduğu gibi spor ortamında da karşılaşılan bir durumdur. Kişiler takım arkadaşları, takım kaptanları, antrenörler, taraftarlar, rakip takım tarafından mobbinge maruz kalabilirler. Lazarević, Krstić ve Sobek, (2015), spor kulüplerinde bir çok mobing türünün olduğunu ifade etmektedirler. Onlara göre özellikle, antrenörlerin sporcularının dayanıklılık seviyelerinin üzerinde antrenman yaptırmalarının sağlık, spor, ahlaki, etik ve değerlere karşı bir durum olduğunu bunun da mobing olarak değerlendirildiğini ifade etmektedirler. Aynı zamanda bu davranışlar, genç sporcuların sağlığını ve gelişimini önemli ölçüde etkileyebilecek davranışlar olarak kabul edilmektedir (Lazarević, Krstić ve Sobek, 2015).

Gül'e (2009) göre, kişi çoğunlukla yüksek performans gösterdiği zamanlarda yıldırılmaktadır. Yıldırma davranışına maruz kalan kişiler, çoğunlukla yüksek iradeli, çalışkan, dürüst ve üretken insanlardır. Bu kişilerin, iş yaşamında, başarıları kıskanılmakta buna bağlı olarak da ilerlemeleri engellenmeye çalışılmaktadır. Yıldırmaya maruz kalındığ 1 durumlarda da, örgütsel yapılanmadan, iş kaybı korkusundan, çalışma arkadaşlarının destek olmamasından, kişilerin çatışma ortamına girmekten çekinmesinden dolayı da mağdurun yıldırma sürecinin devam ettiği ileri sürülmektedir (Gül, 2009).

Günümüzde mobbing uygulamak bir suç olarak kabul edilmektedir. Ama hakaret, aşağılama, alay etme gibi davranışların yanı sıra cinsel taciz daha çok kabul edilmektedir. Mobbing ile ilgili yaptırımlar artarsa, bununla ilgili hukuki düzenlemeler gelirse mobbing uygulamak azalabilir. Sadece hukuki düzenlemenin artması bir çözüm olmayabilir. Örgüt ve kişilerde buna biraz olsun çözüm bulabilirler. Mobbinge maruz kalan kişiler ne kadar bilinçli ve özgüven sahibi olursa bu süreçle daha kolay başa çıkabilirler. Veya örgüt ortamlarında çok sık çatışma oluyorsa üstler bunları önceden kontrol altına almalıdır. Özellikle spor ortamında 
belli bir çatışma varsa antrenörler bunu önceden fark etmeli ve gerekli önlemleri almalarının gerekli olduğu düşünülmektedir.

Ülkemizde spor ortamında yapılan mobing ile ilgili çalışmalar incelendiğinde özellikle son yıllarda çalışmaların arttı̆̆g görülmektedir (Filiz, Kemeç ve Ataşoğlu,2019; Hacıcaferoğlu ve Çoban, 2011; İyem, 2007; Karı ve Yıldız, 2015; Salman ve Yalçındağ, 2017; Üstün ve Pulur, 2016; Yıldız; 2015; Yıldız, Yıldız ve Kepoğlu, 2018). Ancak alanyazı incelendiğinde özellikle takım sporlarındaki sporcuların karşılaştıkları mobbingin nedenleri, süreçleri ve sonuçları ile mobbingin engellenmesine öneri niteliğinde çok fazla çalışma olmadığı görülmüştür. Bu bağlamda bu çalışmanın amacı; erkek takım sporcuları özelinde takım sporcularının mobbing ile ilgili görüşlerinin incelenmesidir.

\section{Mobbing Kavramı}

Davenport, Schwartzve ve Elliott'a (1999) göre, Mob sözcüğü, yasa diş1 şiddete başvuran düzensiz kalabalık şeklinde ifade edilmektedir ve Latince'de "kararsız kalabalık", "şiddete yönelmiş topluluk" gibi anlamlara gelen "mobile vulgus" kelimelerinden oluşmaktadır (Davenport, Schwartzve ve Elliott, 1999).

Leymann'a (1996) göre; Mobbing, ilk olarak etoloji uzmanı Avusturyalı Konrad Lorenz tarafından ortaya atılmıştır. Ona göre mobbing, bir hayvan grubu davranışı olarak, küçük hayvan gruplarının, tehdit olarak gördükleri büyük bir tek hayvanı korkutmak için yaptıkları davranış olarak tanımlamıştır. Sonrasında, İsveçli endüstri psikoloğu olan Peter Paul Heinemann, çocukların sınıf içinde ki davranışlarını incelemiş ve bir grup çocuğun, tek bir çocuğa yönelik tahrip edici davranışını tanımlarken, mobbing kavramını kullanmıştır (Çiftçi, Öneren ve Önem, 2013).

Mobbing, duygusal bir saldırı ve taciz türüdür olarak tanımlanmaktadır (Alparslan ve Tunç, 2009). Aynı zamanda mobbing kavramı, "bir kişinin, diğer kişileri kendi istekleri ile veya istekleri dışında başka bir kişiye karşı sürekli kötü niyetli hareketlerde bulunma, ima, dalga geçme ve karşısındaki kişinin toplumsal itibarını zedeleme gibi yollarla, saldırgan bir ortam yaratarak kişiyi işten çıkmaya zorlaması olarak" tanımlanmaktadır (Davenport, Swartz ve Elliott, 2003). Aynı zamanda mobbing, saldırıda bulunan kişinin, saldırıya maruz kalan kurbanı, davranışına suç ortağı yaptığı planlı ve etkili bir yıpratma girişim olmakla birlikte işyerinde saldırgan ve gergin bir ortam yaratılarak kurbanın işten kovulmasına kadar varabilen bir dizi sataşmaları içermektedir (Alparslan ve Tunç, 2009).

\section{Sporda Mobbing}

Tüm dünyada toplumsal bir olgu olarak bilinen, kitleleri sürükleyen heyecan ve estetik duygusu kazandıran, rekabet kazanma güdüsü, fiziksel ve zihinsel bir gayret olarak tanımlanabilen "Spor" kavramı insanların varoluşundan bu yana toplumun değişmeyecek bir parçasıdır. Günümüzdeki spor ortamında rekabetin 1900'lü yıllara göre çok daha fazla olduğu düşünülürse, içinde bulunduğumuz zamanda mobbing olarak kabul edilecek yüzlerce davranış gerçekleşmektedir. Şuanda dünyanın her yerinde ırkçılık davranışları kınanmakta ve hatta bu saldırılarda bulunanlara ceza yaptırımları uygulanmaktadır. Aslında bu davranış1 spor ortamında olması oldukça üzücü bir durumdur. Çünkü spor dil, din ve ırk ayırmaksızın 
kardeşlik ilkesini de taşımaktadır. Rakibe üstünlük kurma veya kendi kabiliyetsizliğini rakibe yıkma adına, konsantrasyon bozma gibi fair play dışı davranışlarda bu bağlamda aslında sporda mobbing olarak ele alınabilir (Öntürk, 2018).

Lazarević ve diğerleri (2015) çalışmalarında; Spor kulüplerinde mobbing biçimi olarak fiziksel taciz, saldırgan davranış biçimlerinin gittikçe daha görünür olduğu sporda rekabetin çağdaş analizi açısından ilginç olabilecek araştırma örneğimizde mevcut değildir. Cinsiyete ilişkin sonuçların analizine bakıldığında, sadece kadın sporcuların fiziksel şiddete maruz kalmadıklarını, erkek sporcuların da olduğunu göstermektedir. Erkek sporcular için katıldıkları sporların daha fazla saldırganlık, güç, temas vb. talep ettiğine dair net bir açıklama vardır. Bu yüzden eğitimlerinin 'kontrollü saldırganlık' olarak tanımlanan davranış unsurlarını içermesi gerekir ve çoğu zaman sporcuların davranışları bazı şiddet biçimlerine dönüşür. Sonuçta bu, eğitim sürecinde ve rekabette davranışın etik dışı davranış alanına taşındığı çağdaş spor eğilimidir. Kadın sporcular için, sonuçlar fiziksel şiddet olmadığını ve sporu şiddet olarak görmediklerini göstermektedir. Bu tür sonuçların açıklaması koçların pedagojik çalışmalarında ve kulüp ve organizasyonlardaki diğer faktörlerde bulunabilir, ancak geleneksel olarak kadınlar için spor güç, saldırganlık, şiddet vb.dir. Sporun uzmanların eğitim ve pedagojik faaliyetinin gençlerin gelişimi ve ifadesi için hayati önem taşıdığı ve bu tür tacizlerin spor ve spor kulüplerinin değer sistemini ve sporcuların rolünü azalttığı bir alan olduğu düşünülmektedir. sporcuların\% 85,2'si motivasyon eksikliği, kötü ruh hali, korku vb. gibi olumsuz psikolojik semptomlara sahiptir. Sporcular ayrıca baş ağrısı, kronik yorgunluk, artmış kalp hızı gibi fiziksel semptomlardan da muzdariptir (Lazarević, Krstić ve Sobek, 2015).

Yıldız'a (2015) göre, bir basketbol takımındaki iyi bir oyuncu mobbinge maruz kaldığında yüksek düzeyde tükenmişlik yaşarsa takım iyi bir oyuncusunu kaybedebilir ya da takımlarında dışlanma ve küçümsenme gibi kişiye yönelik kötü davranışlar ile hakların verilmemesi gibi işe yönelik kötü davranışlarla karşılaştıklarında sporcuların mesleki tükenmişlik düzeyleri artabilir (Karık ve Yıldız, 2015). Bu gibi durumlar oyuncuların performansları başta olmak üzere takım performansını da olumsuz yönde etkileyebilir. Rakiplerine göre daha başarılı olmak isteyen takımlara, sosyal bağları güçlendirici bir takım kültürü yaratmak ve mobing konusu ile ilgili eğitimler vermek yararlı olabilecektir. Mobbingin yaşanması durumunda ise, varolan problemin giderilebilmesi için 1lımlı, tarafsız, dengeleyici ve liderlik özelliğine sahip yönetici, antrenör ve diğer oyuncular gibi kişilerin devreye girmesiyle yaşanan olumsuz durumlar en az seviyeye indirilebilir (Y1ldız, 2015).

\section{YÖNTEM}

Araştırmanın Modeli: Araştırmada nitel araştırma yöntemleri kullanılmıştır. Nitel araştırma; araştırma yapılacak kişilerin sosyal ortamları içerisinde, kişilerin doğal görünümleriyle gözlem, görüşme ya da belgeleri değerlendirmek yoluyla bilgi edinme ve bu bilgileri analiz ederek kuram geliştirme olarak tanımlanabilir (İslamoğlu ve Alnıaçık, 2016). 
Araştırma Grubu: Araştırma grubu futbol, basketbol, hentbol ve voleybol branşlarıyla uğraşan, amatör ve profesyonel kulüplerde oynayan sporculardan oluşmaktadır. Araştırmanın çalışma grubu yaşları 18-28 arasında değişen, ortalama 10 yıl sporculuk geçmişi olan, araştırmaya gönüllü olarak katılan 20 erkek takım sporcusundan oluşmaktadır (Tablo 1).

Tablo 1. Katılımcılara iliş̧in kişisel bilgiler

\begin{tabular}{|c|c|c|c|c|}
\hline Katılımcı & Yaş & Branş & Sporculuk düzeyi & Sporculuk süresi \\
\hline K1 & 18 & Futbol & Profesyonel & $12 \mathrm{y} 1 \mathrm{l}$ \\
\hline $\mathrm{K} 2$ & 18 & Futbol & Amatör & 6 y1l \\
\hline K3 & 20 & Futbol & Amatör & $11 \mathrm{y} 1 \mathrm{l}$ \\
\hline K4 & 20 & Futbol & Profesyonel & 5 y1l \\
\hline K5 & 19 & Futbol & Profesyonel & $13 \mathrm{y} 1 \mathrm{l}$ \\
\hline K6 & 22 & Basketbol & Amatör & 8 yil \\
\hline K7 & 23 & Basketbol & Amatör & $15 \mathrm{y} 1 \mathrm{l}$ \\
\hline K8 & 26 & Basketbol & Profesyonel & $19 \mathrm{y} 1 \mathrm{l}$ \\
\hline K9 & 24 & Basketbol & Profesyonel & $15 \mathrm{y} 1 \mathrm{l}$ \\
\hline K10 & 24 & Basketbol & Profesyonel & 9 yil \\
\hline K11 & 25 & Hentbol & Profesyonel & $13 \mathrm{y} 11$ \\
\hline K12 & 22 & Hentbol & Profesyonel & $12 \mathrm{y} 1 \mathrm{l}$ \\
\hline K13 & 23 & Hentbol & Profesyonel & $11 \mathrm{y} 1 \mathrm{l}$ \\
\hline K14 & 28 & Hentbol & Profesyonel & $19 \mathrm{y} 1 \mathrm{l}$ \\
\hline K15 & 18 & Hentbol & Profesyonel & $10 \mathrm{y} 1 \mathrm{l}$ \\
\hline K16 & 18 & Voleybol & Profesyonel & $3 \mathrm{y} 11$ \\
\hline K17 & 18 & Voleybol & Profesyonel & 7 y1l \\
\hline K18 & 18 & Voleybol & Profesyonel & 5 y1l \\
\hline K19 & 20 & Voleybol & Profesyonel & 4 yıl \\
\hline $\mathrm{K} 20$ & 19 & Voleybol & Profesyonel & 5 y1l \\
\hline
\end{tabular}

\section{Veri Toplama Araçları}

Araştırmada nitel araştırma tekniklerinden görüşme yöntemi kullanılmıştır. $\mathrm{Bu}$ yöntem çeşidinden de 'Yarı Yapılandırılmış Görüşme' kullanılmıştır. Görüşmecilere 2 kısımdan oluşan sorular yöneltilmiştir. İlk kısımda kişisel bilgiler yer almaktadır. İkinci kısımda ise takım sporcularının mobbing ile ilgili görüşlerini öğrenmek için 6 tane soru yöneltilmiştir.

\section{Görüşmeler}

Görüşme öncesi katılımcılardan randevu alınmıştır. Görüşmeye başlamadan önce katılımcılara konu hakkında bilgi verilmiştir. Ses kayıt cihazı ile görüşmeler kaydedilmiştir. Ses kayıt işlemi araştırmacı tarafından yapılmıştır. Bilgi formu ve görüşme soruları, araştırmacı ve alanında uzman 2 kişiyle birlikte hazırlanmıştır.

Çalışmanın geçerliliğinde; bulguların tutarlı ve anlamlı olmasına dikkat edilmiştir. Ayrıca, araştırmada elde edilen bulgular, araştırmacı tarafından hem ses kayıt cihazına kaydedilmiş hem de kısa notlar yoluyla kayıt altına alınmıştır. Araştırmanın güvenirliliğinde ise; araştırmacılar, araştırmanın yöntemlerini ve aşamalarını açık ve ayrıntılı bir biçimde tanımlamış, veriler araştırma sorularının gerektirdiği şekilde ayrıntılı ve amaca uygun bir biçimde elde edilmiştir. Son olarak; araştırmanın sonuçları araştırmanın verileri ile uyumlu bir şekilde sunulmuştur (Yıldırım ve Şimşek, 2011). 


\section{Verilerin Analizi}

Araştırmada, "betimsel analiz" yöntemi kullanılmıştır. Betimsel analiz yöntemi, verilerin anlaşılır bir biçimde çözümlenmesine, neden sonuç ilişkilerinin derinlemesine incelenrek sonuçlara ulaşılmasına ve bulguların yorumlanmasına olanak sağlamaktadır (Yıldırım ve Şimşek, 2011).

Görüşme sırasında yapılan ses kayıtları bilgisayarda yazıya geçirilerek kaydedilmiştir. Kayıtlar tek bir metin halinde toplanarak kodlanmıştır. Strauss ve Corbin'in (1990) "verilerden çıkarılan kavramlara göre yapılan kodlama" biçiminden yola çıkarak araştırma verilerinin kodlanması sağlanmıştır. Bu kodlama türü sayesinde araştırmacı metini okur ve araştırmanın amacından yola çıkarak önemli hususları belirler. Elde ettiği anlamlardan kodlar çıkarabilir veya verilerden kodlar oluşturabilir. Böylece tüm verilerin işlenebilmesi için kavramsal yapı ile birlikte kod listesi de oluşmaktadır. Tümevarımcı analizde kodlar verilerden üretilmektedir (Yıldırım ve Şimşek, 2011).

\section{BULGULAR ve TARTIŞMA}

Araştırmanın bu bölümünde, katılımcıların spor ortamında karşılaştıkları mobbing davranışlarına ilişkin görüşleri şekiller ve tablolar şeklinde sunulmuştur. Ayrıca, katılımcı görüşlerine ait kodlar, alt temalar ve bazı katılımcı görüşlerine yer verilerek araştırmanın bulguları tartışılmıştır.

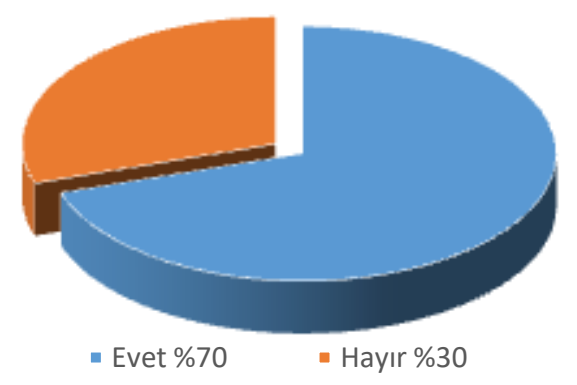

Şekil 1. Mobinge maruz kalan katılımcılar

Şekil.1 incelendiğinde takım sporcularının \%70'inin mobbinge maruz kaldığı gözlemlenirken, \%30’unun mobbinge maruz kalmadığı gözlemlenmiştir.

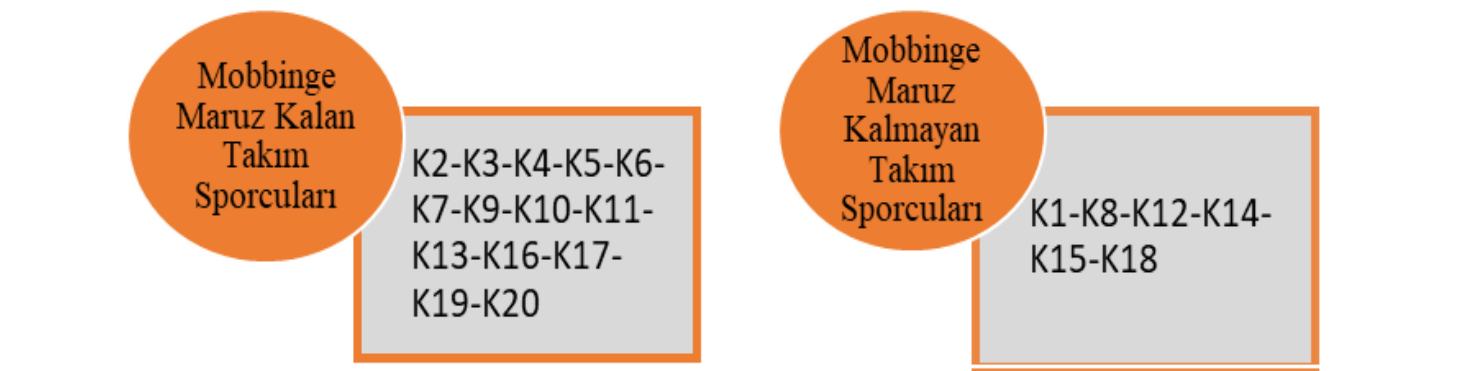

Şekil 2. Mobbinge maruz kalan ve kalmayan takım sporcuları 
Şekil 2’de Mobinge maruz kalan ve kalmayan takım sporcuları görülmektedir.

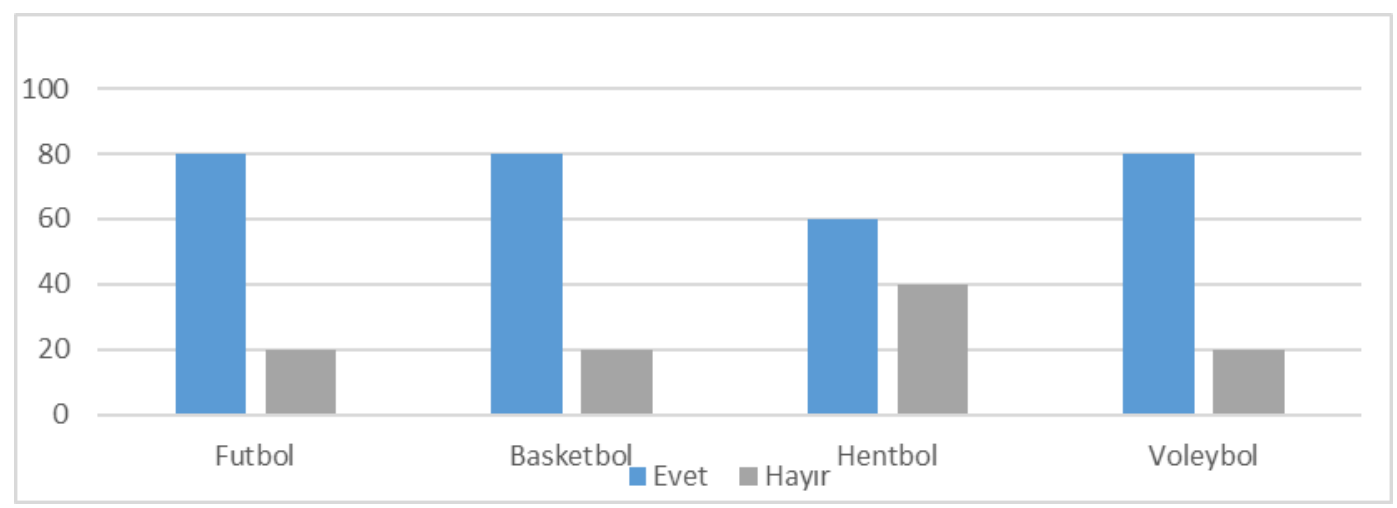

Grafik 1. Takım sporcularının branşlarına göre mobinge maruz kalma durumları

Takım sporcularının mobbinge maruz kalma dağılımları incelendiğinde futbol, basketbol ve voleybol branşlarında \%80'inin mobinge maruz kaldığı, hentbol branşındaki takım sporcularının ise \%60'ının mobbinge maruz kaldığg görülmektedir (Grafik 1).

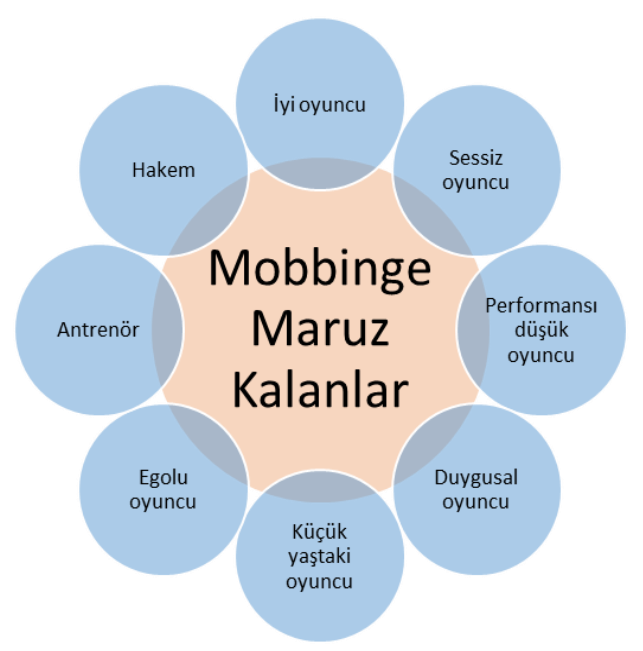

Şekil 3. Katılımcı görüşlerine göre "Spor Ortamında Mobbinge Maruz Kalan Kişiler” ile ilgili bulgular

Katılımcıların, spor ortamında mobbinge maruz kalan kişiler ile ilgili görüşleri incelendiğinde; 'iyi oyuncu', 'sessiz oyuncu', 'duygusal oyuncu', 'performansı düşük oyuncu', 'küçük yaştaki oyuncu', 'egolu oyuncu', 'hakem', 'antrenör' gibi kavramlar üzerinde durdukları görülmüştür (Şekil 3). 
Tablo 2. Spor ortamında mobbinge maruz alan kişiler ile ilgili görüşme sonucu ortaya çıkan kodlar, alt temalar ve bazı katılımcı görüşleri

\begin{tabular}{llc}
\hline $\begin{array}{l}\text { Görüşme sonucu ortaya } \\
\text { çıan kodlar }\end{array}$ & Alt temalar & f \\
\hline En iyi oyuncular & İyi oyuncu & 4
\end{tabular}

\begin{tabular}{lll}
\hline Sessiz olan oyuncular & Sessiz oyuncu
\end{tabular}

\begin{tabular}{llc}
\hline Duygusal olan sporcular & Duygusal oyuncu & 2 \\
\hline $\begin{array}{l}\text { Performansı düşük olan } \\
\text { oyuncular }\end{array}$ & $\begin{array}{l}\text { Performansı düşük } \\
\text { oyuncu }\end{array}$ & 2 \\
\hline
\end{tabular}

\begin{tabular}{ll}
\hline $\begin{array}{l}\text { Yaşı küçük olan } \\
\text { oyuncular }\end{array}$ & $\begin{array}{l}\text { Küçük yaşta } \\
\text { oyuncu }\end{array}$ \\
\end{tabular}

\begin{tabular}{lll}
\hline Egolu oyuncular & Egolu oyuncu & 1 \\
& & \\
\hline Hakemler & Hakem & 2
\end{tabular}

\begin{tabular}{lll}
\hline Antrenörler & Antrenör & 1 \\
\hline
\end{tabular}
K1: "En iyiler. Bir ortamın en iyisi. Mesela Barcelona'da Messi Juventus'ta Ronaldo. Bence baskilar bunun üzerinde olur genelde."
K13: “...çok sivrilirsin aralarında bu sefer bir şeylerin önüne geçmeye başlayınca performans olarak, yaşı büyüklerde ego fazla olduğu için kendi önüne geçirmemek amacıyla mobbinge maruz kalınır."
K2: "Daha çok bence sessiz olanlar, girişken olmayanlar karşılaşabilir."
K16: "Pasif insanlar. Daha böyle az sesi çıkan insanlar."
K3: "Duygusal olanlar daha fazla maruz kalır." K4: "Bu takım sporunda daha çok performansı düşük olan kişiler ya da takımın içindeki farklı insanlar, kötü insanlar tabirini kullanayım. Karşılaşabilir bu kişiler."
K8: "Yani çoğunlukla sporcularda mobbingle karşılaşanlar küçük oyuncular oluyor. Çünkü onlara laf geçirilebiliyor." K11: "Öncelikle yaşı küçük olan sporcular takımdaki daha tecrübeli bireyler istenmeyen bir davranış olduğu zaman kızabiliyorlar."
K20: “...Çok pasifsen maruz kalırsın ya da çok egolusundur ki ben bundan çok çektim. Sen sus büyükler varken sen kimsin dediler."

K15: "Bence hakemler karşıllaşır. Daha çok onlara psikolojik taciz yapılıyor diye düşünüyorum. Sporcuya maçta kazandığ 1 sürece bir şey yok, kaybettiği sürece vardır."

K10: “...antrenöre yapılır.”

Öntürk’e (2018) göre, spor ortamında en yaygın mobbing davranışı sporculara yapılmaktadır. Yapılan her türlü davranışın sonucunda sporcular olumsuz etkilenmektedir. Sporcuların yanı sıra antrenörlerinde mobbing kurbanı oldukları oldukça sık görülmektedir. Aynı zamanda, takım içerisinde sporcuların kendi aralarında yaş veya başka değişkenlere göre oluşturdukları hiyerarşik durumlar olduğunu ve amatör sporlar değerlendirildiğinde genelde malzeme vs. gibi araç gereçleri yaşı en küçük olan veya yeni gelen sporcular taşır şeklinde bir norm olduğunu ifade edilmektedir (Öntürk, 2018). Bu bağlamda, küçük yaştaki oyunculara yaş1 büyük olan sporcuların mobbing yaptığını söylemek mümkündür. Aynı zamanda, araştırmada da sadece oyuncuların değil aynı zamanda antrenörler ve hakemlerin de spor ortamında mobbinge maruz kalabileceği katılımcı görüşleri neticesinde ortaya çıkmaktadır. 


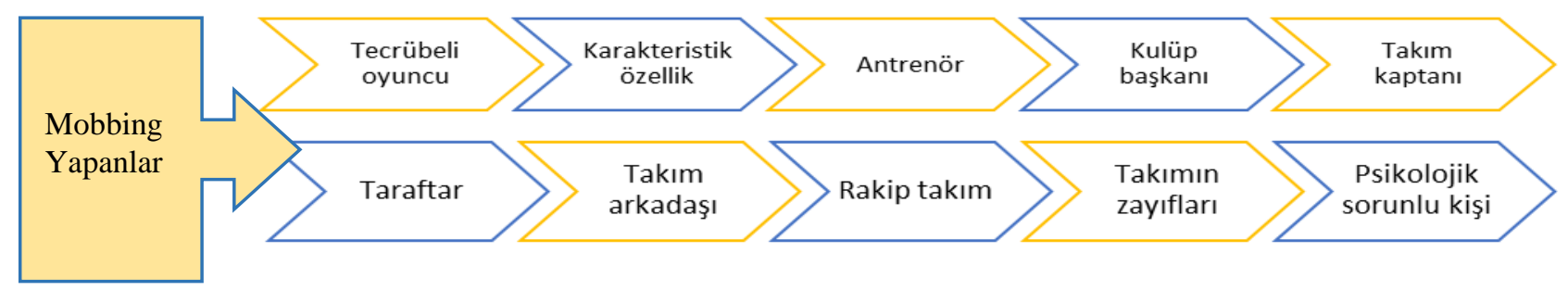
bulgular

Şekil 4. Katılımcı görüşlerine göre "Spor Ortamında Mobbing Yapan Kişiler" ile ilgili

Katılımcıların spor ortamında mobbing yapan kişiler ile ilgili görüşleri incelendiğinde; 'tecrübeli oyuncu', 'karakteristik özellik', 'antrenör', 'kulüp başkanı', 'takım kaptanı', 'takım arkadaşı', 'rakip takım', 'taraftar', 'takımın zayıfları', 'psikolojik sorunlu kişiler' gibi kavramlar üzerinde durdukları görülmüştür (Şekil 4).

Tablo 3. Spor ortamında mobbing yapan kişiler ile ilgili görüşme sonucu ortaya çıkan kodlar, alt temalar ve bazı katılımcı görüşleri

\begin{tabular}{|c|c|c|c|}
\hline $\begin{array}{l}\text { Görüşme sonucu ortaya } \\
\text { çıkan kodlar }\end{array}$ & Alt temalar & f & Bazı Katılımcı Görüşleri \\
\hline $\begin{array}{l}\text { Yaşça büyükler ve tecrübeli } \\
\text { kişiler }\end{array}$ & Tecrübeli oyuncu & 5 & $\begin{array}{l}\text { K12: “....antrenörün bir şey demediği ya da } \\
\text { kendinden yaşça küçüklere yaşça büyükler } \\
\text { uygulayabiliyor." } \\
\text { K13: “...yaşı büyüklerde ego fazla olduğu } \\
\text { için kendi önüne geçirmemek amacıyla } \\
\text { mobbinge maruz kalınır.” }\end{array}$ \\
\hline $\begin{array}{l}\text { Karakteristik özelliği uygun } \\
\text { olan kişiler }\end{array}$ & Karakteristik özellik & 8 & $\begin{array}{l}\text { K1: “...aslında yapabilecek karakter var } \\
\text { yapamayacak karakter var. Yani tamamiyle } \\
\text { karakteristlik özelliklerine bağlı olduğunu } \\
\text { düşünüyorum.” } \\
\text { K4: “...̧̇̇çi kötü olanlar yapıyordur. Kişinin } \\
\text { karakterine kalmış bir şeydir." }\end{array}$ \\
\hline Antrenörler & Antrenör & 3 & $\begin{array}{l}\text { K2: "Hocalarımız, antrenörlerimiz oluyor } \\
\text { genelde..." } \\
\text { K19: "En çok başantrenör uygular..." }\end{array}$ \\
\hline Kulüp başkanları & Kulüp başkanı & 1 & K2: “...̇̇lerisi başkanlar falan uygular.” \\
\hline Takım kaptanları & Takım kaptanı & 2 & $\begin{array}{l}\text { K3: "Takım kaptanıdır mesela ama kötüye } \\
\text { kullanıyordur." }\end{array}$ \\
\hline Taraftarlar & Taraftar & 3 & $\begin{array}{l}\text { K15: "Bence en çok taraftarlar yapıyor. } \\
\text { Sporcuların kendi içerinde pek böyle şeyleri } \\
\text { yok diye düşünüyorum." }\end{array}$ \\
\hline Takım arkadaşları & Takım arkadaşı & 3 & $\begin{array}{l}\text { K6: "Takım arkadaşları. Birisi birisini } \\
\text { çekemiyor diğer takım arkadaşı da gidiyor } \\
\text { ona sürekli takım içersinde mobbing } \\
\text { uyguluyor onu düşürmeye ki çalışıyor onun } \\
\text { yerine geçip oynayabilmek için." }\end{array}$ \\
\hline Rakip takım & Rakip takım & 3 & K10: “...Rakibin daha çok yapıyor. \\
\hline $\begin{array}{l}\text { Takımdaki en beceriksiz } \\
\text { kişiler }\end{array}$ & Takımın zayıfları & 1 & $\begin{array}{l}\text { K7: "Takımdaki en beceriksiz kişiler } \\
\text { genelde." }\end{array}$ \\
\hline $\begin{array}{l}\text { Psikolojik sorunları olan } \\
\text { kişiler }\end{array}$ & $\begin{array}{l}\text { Psikolojik } \\
\text { kişi }\end{array}$ & 1 & $\begin{array}{l}\text { K9: "...psikolojik sorunları olan insanlar } \\
\text { tarafindan maruz kalıyorlar." }\end{array}$ \\
\hline
\end{tabular}


Mobbing, örgütün hiyerarşik düzeni içerisinde dikey ve/veya yatay olarak uygulanır. Tutar (2004)'a göre, dikey veya başka bir ifade ile 'hiyerarşik mobbing'de üstler astlarına veya astlar üstlerine mobbing davranışlar da bulunurken; yatay veya fonksiyonel mobbingde ise, kurmay-fonksiyonel ilişki içinde olan kişiler birbirlerine mobbing uygularlar (Tutar, 2004). Örgütlerde meydana gelen dikey mobbing astlarla üstler arasındadır. Spor ortamında ise bu durum kulüp başkanlarının sporculara uygulaması, antrenörün sporcuya uygulaması olarak karşımıza çıkmaktadır. Çalışmalar incelendiğinde de antrenörlerin performanslarının örgütlerde olan yatay mobbing ise spor ortamında takım arkadaşlarının birbirine mobbing yapması ve tecrübeli oyuncuların yaşı küçük oyunculara mobbing yapması yatay mobbing olarak karşımıza çıkmaktadır.

Katılımcılar, aynı takımda oynayan oyuncuların da birbirlerine mobing yapabileceği yönünde görüş bidirdikleri görülmektedir. İyem'in (2007) futbolda mobbing üzerine yaptığ araştırmada da çalışma ile benzer şekilde; stres halinde olan ve gelecek kaygısı yaşayan futbolcuların, takım arkadaşlarına mobbing uygulayabileceklerini ifade etmektedir. Çalışmada, futbolcuların en çok mobbinge takım arkadaşları tarafından maruz kaldıklarını ve en çok kendilerini takım arkadaşları tarafından yapılan olumsuz davranışlardan etkilendiklerini ifade etmişlerdir (İyem, 2007).

Lazarević ve diğerleri (2015), antrenörlerin sporcularının performansını üst düzeye çıkartabilmek için zorladığını bununda antrenörlerin sporcularına yönelik olarak yaptıkları mobbing davranışı olarak kabul edildiğini ifade etmişlerdir.

Salman ve Yalçındağ (2017), sporun yarışmacı doğasının ve antrenör ile yönetici gibi paydaşların başarı odaklı zorlamaları, Öntürk (2018), Spor kavramı tanımlanırken, "içinde rekabet ve kazanma güdüsü bulunduran" ifadesi aslında bize mobbing davranışlarının çıkış noktasını göstermekte olduğunu ifade etmektedirler. Bu görüşler neticesinde, rekabet olgusu çerçevesinde bulunan herkesin mobbing yapmaya yakın olduklarını söylemek mümkündür.

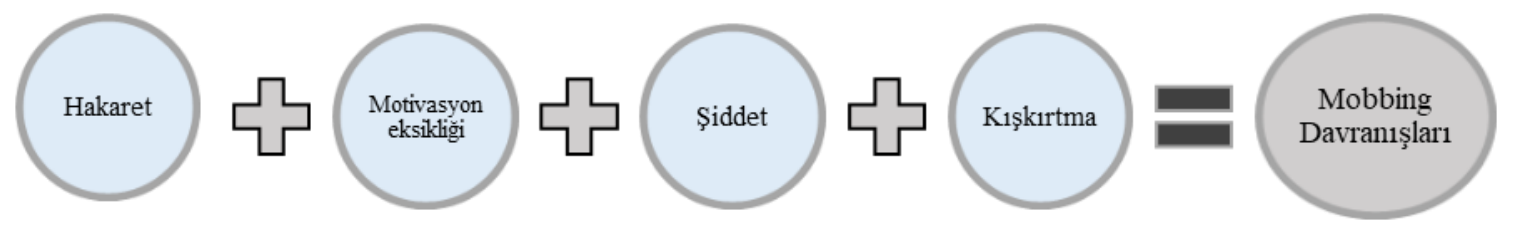

Şekil 5. Katılımcı görüşlerine göre "Spor Ortamında Mobbing Olarak Kabul Edilen Davranışlar" ile ilgili bulgular

Katılımcıların mobbing davranışları ile ilgili görüşleri incelendiğinde; 'hakaret', 'motivasyon eksikliği', 'şiddet', 'kışkırtma' olmak üzere dört kavram üzerinde durdukları görülmüştür (Şekil 5). 
Tablo 4. Spor ortamında mobbing olarak kabul edilen davranışlar ile ilgili görüşme sonucu ortaya çıkan kodlar, alt temalar ve bazı katılımcı görüşleri

\begin{tabular}{|c|c|c|c|}
\hline $\begin{array}{l}\text { Görüşme sonucu } \\
\text { ortaya çıkan kodlar }\end{array}$ & Alt temalar & $\mathbf{f}$ & Bazı Katılımcı Görüşleri \\
\hline $\begin{array}{l}\text { Aşağılayıcı hareketler } \\
\text { ve sözler }\end{array}$ & Hakaret & 10 & $\begin{array}{l}\text { K4: "Çirkin sözler kullanıldığında bu mobbing } \\
\text { diyebilirim.” } \\
\text { K5: "Takımın içinde her türlü kötü konuşma." } \\
\text { K8: “...Alay konusu yapılabilecek bir şaka türü olur. } \\
\text { Onu küçük düşürecek şeylerde olabilir." } \\
\text { K15: "Tezäürat olur bir kişiye karşı yapılan. Kişiye } \\
\text { karşı küfürlü hakaretler.” }\end{array}$ \\
\hline $\begin{array}{l}\text { Performans1 ile ilgili } \\
\text { güzel söz söylemiyorsa }\end{array}$ & $\begin{array}{l}\text { Motivasyon } \\
\text { eksikliği }\end{array}$ & 2 & $\begin{array}{l}\text { K3: "Sporcu performansında gayet başarılıysa ve } \\
\text { antrenör bu kişiye performansının başarılı olduğu } \\
\text { sporcuya iyi yönde laflar veya sözler söylemiyorsa, } \\
\text { başarısını performansını tebrik etmiyorsa, övmüyorsa } \\
\text { şöyle düşünürüm." }\end{array}$ \\
\hline Fiziksel hareketler & Şiddet & 2 & $\begin{array}{l}\text { K9: "... sporun içinde olmayan hareketler olarak } \\
\text { yapıyorlar. Fiziksel olarak böyle yapıyorlar genelde... } \\
\text { dirsek atıyorlar işte kolumdan tutup çekiyorlar." }\end{array}$ \\
\hline Karşı tarafı kışkırtma & Kışkırtma & 4 & $\begin{array}{l}\text { K1: "Kışkırtma olsun nasıl diyeyim bu kişiden kişiye } \\
\text { değişir ama mesela Felipe Melo ve Emre Belözoğlu } \\
\text { arasında maçta bir sıkıntı çıkmıştı. Emre Belözoğlu } \\
\text { kırmızı kart görmüştü. Felipe Melo'da dilini falan } \\
\text { çıkarmıştı. Yani bunlar karşı tarafı kışkırtmaya girer." }\end{array}$ \\
\hline
\end{tabular}

Yapılan mobbing sayılabilecek davranışlara bakıldığında ırkçı söylemler, özel hayat baskısı, ücret ödeme ve indirime gitme konusunda bask1, sözleşmedeki maddelere uymama baskısı, başka kulüp bulunması yönünde baskılar, kadro dışı bırakılma veya sürekli oynatılmama gibi davranışlar üst yönetim ve teknik heyet iş birliği ile sporcuya uygulanan psikolojik baskılardır. Bunların bazılarına mobbing bakış açısı ile bakmak gerekmektedir. Sonuç olarak profesyonel iş yaşantı içinde olmaktadır (Öntürk, 2018). Mobbing sayılabilecek pek çok davranış vardır. Katılımcılar insan psikolojisini bozacak en ufak şeyin bile mobbing sayılabileceğini söylemişlerdir. Alay konusu olabilecek bir şaka, takım içerisinde her türlü kötü konuşma, yapılan kötü tezahürat ya da kişinin performansını övmezsen, sen çok iyisin demezsen bile mobbing sayılabileceğini ifade etmektedir. Aynı zamanda sporda mobbing olarak sayılabilecek davranışlara bakıldığında, Brockkötter'e (2016) göre vurmak veya tekmelemek, hakaretler, sözlü ve sözsüz saldırılar mobing olarak kabul edilmektedir.

\section{Katılımcıların Spor Ortamındaki Mobbing İle İlgili Görüşleri}

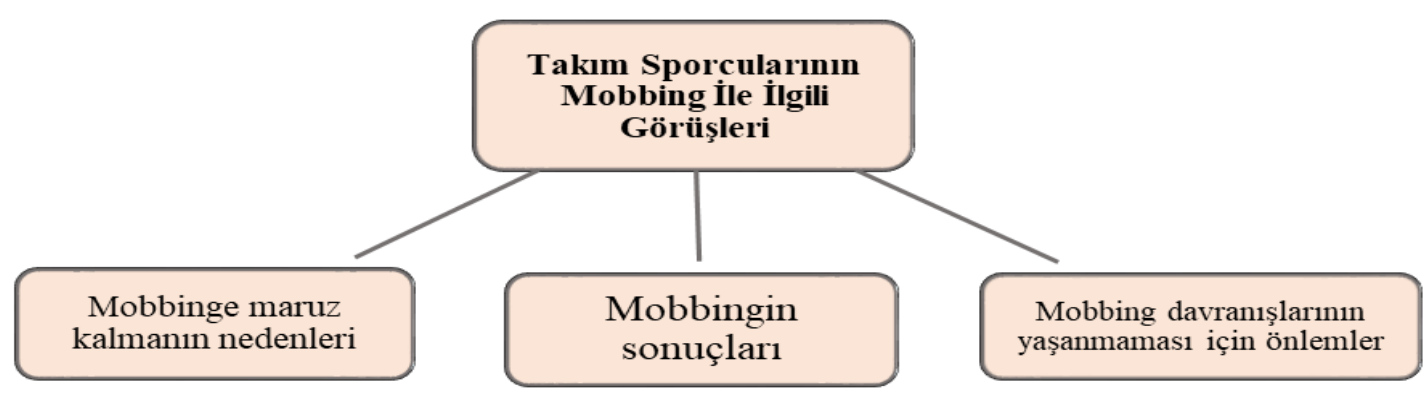

Şekil 6. Genel Tema ve Alt Boyutlar 
1. Ana Tema'da kişilerin mobbinge neden maruz kaldığı ile ilgili görüşler incelendiğinde, verilerin analizi ile yapılan kodlamalar sonucunda; örgütten kaynaklanan nedenler, sosyal gruptan kaynaklanan nedenler ve kişiden kaynaklanan nedenler olmak üzere 3 ayrı tabloda gösterilmiştir.

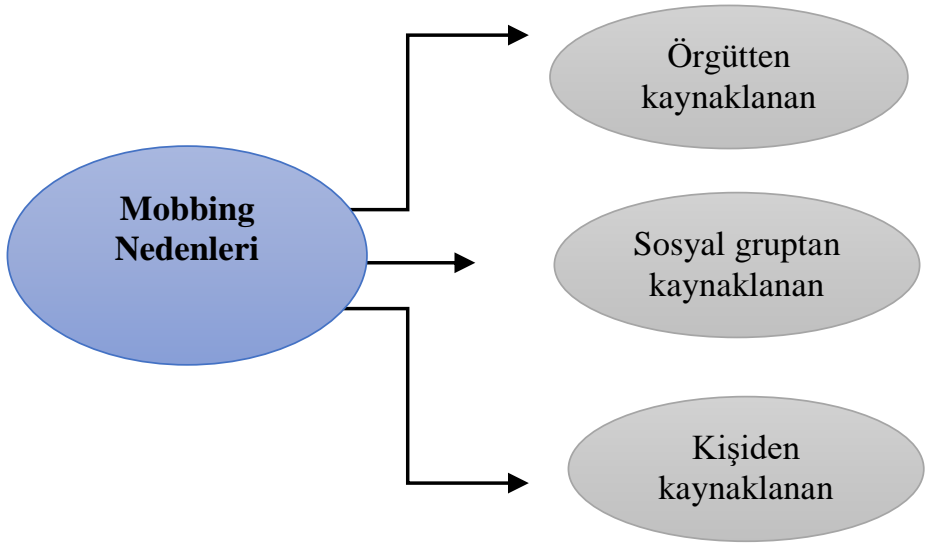

Şekil 7. Mobbing nedenleri

Tablo 5. Mobbing davranışlarına maruz kalmanın örgütten kaynaklanan nedenleri ile ilgili bulgular

\begin{tabular}{|c|c|c|c|}
\hline $\begin{array}{l}\text { Görüşme sonucu ortaya } \\
\text { çıkan kodlar }\end{array}$ & Alt temalar & $\mathbf{f}$ & Bazı Katılımcı Görüşleri \\
\hline Adaletli olmak için & Adalet & 1 & $\begin{array}{l}\text { K3: "Hocalarım adaletli davranmak için aynı mevkidaş } \\
\text { arkadaşlarımla beni eşit sürede oynatmak amacı ile böyle bir adalet } \\
\text { sistemine girdiklerini düşünüyorum." }\end{array}$ \\
\hline Rekabet oluşması & Rekabet & 2 & $\begin{array}{l}\text { K2: "Saha içinde rekabet oluştuğu için iki takım arasında ister } \\
\text { istemez gerginlikler oluşuyor." } \\
\text { K14: "Bir nedeni rekabet yüzündendir." }\end{array}$ \\
\hline Kişinin kötü oynaması istemek & Kötü oynamak & 5 & $\begin{array}{l}\text { K1: “...eğer birisi iyiyse ve ben rakip takımdaysam o kişinin kötü } \\
\text { oynamasını isterim.” } \\
\text { K6: “... biri birisini düşürme hevesi olabilir takımda.” }\end{array}$ \\
\hline Kötü-yetersiz performans & Kötü performans & 4 & $\begin{array}{l}\text { K4: “...o gün maç vardır ve ben kötü oynamışımdır, kötü } \\
\text { performans sergilemişimdir bana hakaret edebilir takım } \\
\text { arkadaşlarım. } \\
\text { K15: "Kazanması gereken bir maçı kazanmıyorsa maruz kalabilir." }\end{array}$ \\
\hline Örgüte uygun olmamak & Uygun olmak & 1 & $\begin{array}{l}\text { K8: “O örgüte, yapıya uygun değilse, o örgüt tarafindan maruz } \\
\text { kalabilir." }\end{array}$ \\
\hline Kişinin sevilmemesi & Sevilmemek & 3 & $\begin{array}{l}\text { K9: "...takımda seni daha çok tutuyorlarsa, seviyorlarsa seni } \\
\text { sevmeyen biri yapabilir." } \\
\text { K12: "Belki sevilmediği için maruz kalır." }\end{array}$ \\
\hline Kıskançlık yapmak & Kıskançlik & 3 & $\begin{array}{l}\text { K10: “...kazanmak için yapar insan her türlü ya da çekemediği, } \\
\text { kıskandığı için olur." } \\
\text { K14: “...Kıskançlıktan olabilir." } \\
\text { K19: "Ya o arkadaşını, o insanı sevmiyordur. Ya da kıskanç } \\
\text { olabilir." }\end{array}$ \\
\hline Bask1 altında olmak & Bask1 & 2 & $\begin{array}{l}\text { K7: "Bizim takımımızda ailesi tarafından kulüp yöneticilerine } \\
\text { baskı yapılan oynatılması gereken kişiler vardı. Onların } \\
\text { oynatılması, onların çembere daha fazla sayı atılması için bize top } \\
\text { atmamamı, top kullanmamamı, topu onlara vermemiz } \\
\text { söyleniyordu. Attığımız zamanda kızılıyordu, oyundan } \\
\text { çıartılıyordu. O yüzden çok fazla mobbinge maruz kaldım oyun } \\
\text { içinde." }\end{array}$ \\
\hline Bilinçsiz olmak & Bilinçsizlik & 1 & $\begin{array}{l}\text { K17: "Bilinçsizlikten oluyor bence. Bizim kulübümüzün yöneticisi } \\
\text { açıkçası voleybol bilgisi sıfir olan biri." }\end{array}$ \\
\hline
\end{tabular}


Katılımcıların örgütten kaynaklanan nedenlerle ilgili görüşleri incelendiğinde; 'adalet', 'rekabet', 'kötü oynamak', 'kötü performans', 'uygun olmak', 'sevilmemek', 'kıskançlık', 'bask1', 'bilinçsizlik’ gibi kavramlar üzerinde durdukları görülmüştür (Tablo 5).

Mobbingin nedenlerini açıklamak için bugüne kadar yeterli araştırma yoktur. Metodolojik problemler fenomenin ampirik incelemesini engeller. Sonuç olarak, genellikle mağdurlarla yapılan görüşmelere dayanan çok sayıda tanımlayıcı vaka raporu bulunmaktadır. Faillerin ve potansiyel vekillerin bakış açıları aranmaz. Mobbingin birden fazla nedeninin göz önünde bulundurulması gerektiği ve mobbingin aynı anda birden fazla faktörden kaynaklanabileceği görüşünü destekleyen veriler sunulacaktır. Mobbing davranışlarının örgütsel nedenlerine bakıldığında; liderlik, organizasyon kültürü, iş stres faktörleri yer almaktadır (Zapf, 1999).

Mobbing, çalışma yaşamında, çalışanların ve örgütlerin sağlık, barış ve verimliliklerinin önünde stres yaratan faktörler olarak kabul edilmektedir (İlhan, 2010). Tinaz’a (2008) göre de; örgüt içinde istenmeyen bir kişiden kurtulmanın amaçlanmasının sonucunda kasıtlı ve gerçek bir psikolojik taciz stratejisi uygulanmaktadır (Tınaz, 2008). Bu araştırmada da örgütten kaynaklanabilecek nedenlerden bazılarının kişiyi sevmemek, kıskançlık, rekabet amaçlı olabileceği gözlemlenmiştir.

Tablo 6. Mobbing davranışlarına maruz kalmanın sosyal gruptan kaynaklanan nedenleri ile ilgili bulgular

\begin{tabular}{|c|c|c|c|}
\hline $\begin{array}{l}\text { Görüşme sonucu } \\
\text { ortaya çıan kodlar }\end{array}$ & Alt temalar & $\mathbf{f}$ & Bazı Katılımcı Görüsşleri \\
\hline Gruplaşmalar & Gruplaşma & 2 & $\begin{array}{l}\text { K2: "Yani futbol içinde gruplaşmalar olduğunda, biri } \\
\text { oynadığında diğeri oynamadığında genelde bu tarz şeyler } \\
\text { olur." }\end{array}$ \\
\hline $\begin{array}{l}\text { Liderlik vasfi yüksek } \\
\text { olan kişilerce }\end{array}$ & Liderlik & 1 & $\begin{array}{l}\text { K3: “...liderlik özelliği ağır basan arkadaşlarımın } \\
\text { mobbingine maruz kalıyordum.” }\end{array}$ \\
\hline $\begin{array}{l}\text { Karşı tarafin moralini } \\
\text { bozmak }\end{array}$ & Moral bozmak & 2 & $\begin{array}{l}\text { K1: “...Karşı tarafin moralini bozmaya çalışıyordur." } \\
\text { K4: "Yapmamam gereken veya onun hakkında yapmamam } \\
\text { gereken bir şey yapmışımdır, Mesela onu sinir etmişimdir } \\
\text { ya da onunla ilgili kötü bir şey söylemişimdir." }\end{array}$ \\
\hline D1ş görünüş & Görünüşs & 2 & $\begin{array}{l}\text { K7: "Bizim saha içindeki değil de saha dışındaki } \\
\text { hareketlerimizden dolayı mobbinge maruz kalınıyor. } \\
\text { Mesela takımda giyiniş çok önemlidir. Bütün takım Adidas } \\
\text { eşofman giyiyorken birisi gidip pazardan aldığı eşofmanı } \\
\text { giyiyorsa onunla çok fazla dalga geçilir." }\end{array}$ \\
\hline Fikir ayrıllı̆ı & Fikir ayrılığ1 & 3 & $\begin{array}{l}\text { K8: “Çoğunlukla görüş ayrılıkları. Yani dinsel olur, başka } \\
\text { konularda da olur.” } \\
\text { K9: “...fikir ayrılıkları yüzünden spor içinde oluyor.” }\end{array}$ \\
\hline Kişisel amaçlar & Kişisel amaçlar & 1 & $\begin{array}{l}\text { K11: "Öncelikle profesyonel sporcuysanız daha çok kendi } \\
\text { amaçlarınız vardır..." }\end{array}$ \\
\hline Eğlence amaçlı & Eğlence & 1 & $\begin{array}{l}\text { K18: "Genelde eğlenmek için yaparız biz. Arkadaşlarımız } \\
\text { arasında birbirimize bu baskıyı kurarız ama sadece beraber } \\
\text { eğlenmek için dalgasına yaptığımız şeyler oluyor." }\end{array}$ \\
\hline
\end{tabular}

Katılımcıların sosyal gruptan kaynaklanan mobbing nedenleri ile ilgili görüşleri değerlendirildiğinde; 'gruplaşma', 'liderlik', 'moral bozmak', 'görünüş', 'fikir ayrılı̆̆g', 'kişisel amaçlar', 'eğlence' gibi kavramlar üzerinde durdukları görülmüştür (Tablo 6). 
Mobbing, sosyal iklimde sosyal desteğin azalmasına yol açabilir ve bu da bilgi akışını zayıflatabilir. Yine, bu belirsizlik (hedefe ulaşma ile ilgili) ve organizasyon sorunları gibi iş streslerini artırabilir. Mobbingin sosyal gruptan kaynaklanan nedenleri arasında; düşmanlık, imrenme, grup baskısı ve günah keçisi yer almaktadır (Zapf, 1999).

$\mathrm{Bu}$ araştırmada katılımcılar dış görünüşten dolayı kişilerle alay edilebileceğin, eğlence için arkadaşlarıyla dalga geçilebileceği, mobbinge maruz kalabileceği söylemişlerdir. Buna ek olarak gruplaşmalar, karşı tarafın moralini bozmak, fikir ayrılıkları, liderlik ve kişisel amaçlarda sosyal nedenler arasına girebileceği gözlemlenmiştir.

Tablo 7. Mobbing davranışlarına maruz kalmanın kişiden kaynaklanan nedenleri ile ilgili bulgular

\begin{tabular}{|c|c|c|c|}
\hline $\begin{array}{l}\text { Görüşme sonucu } \\
\text { ortaya çıkan kodlar }\end{array}$ & Alt temalar & $\mathbf{f}$ & Bazı Katılımcı Görüşleri \\
\hline Özgüven eksik olması & Özgüven & 6 & $\begin{array}{l}\text { K2: "Sahada ya da antrenmanlarda özgüven } \\
\text { eksikliğinden olabilir." } \\
\text { K8: "…'̧̇ine kapanık olmasından, kendine } \\
\text { güveni olmamasından dolayı çok fazla } \\
\text { mobbinge maruz } \\
\text { K20: "Özgüveni olmayan insan bence kalır. } \\
\text { Konuşamayan insan, kendini anlatamayan insan } \\
\text { maruz kalır." }\end{array}$ \\
\hline Duygusal yapılı olmak & Duygusal & 4 & $\begin{array}{l}\text { K8: "Çok fazla duygusal olmasından insanın." } \\
\text { K11: "Özellikle duygusal yönlerimiz çok etkili } \\
\text { olur. Çünkü insanın duygusal tarafı ağır } \\
\text { bastıkça daha çok küçük problemleri büyütebilir } \\
\text { kafasında." }\end{array}$ \\
\hline Arkadaş canlısı olmak & Arkadaş canlısı & 2 & $\begin{array}{l}\text { K3: “...Çok arkadaş canlısıyım. Bu yüzden } \\
\text { mobbinge aşırı derecede maruz kalabiliyorum." } \\
\text { K19: “...Samimi ilişkiler kurduğum için kısa } \\
\text { dönemli maruz kalabiliyorum.” }\end{array}$ \\
\hline Sivri karakterli olmak & Sivri karakter & 1 & $\begin{array}{l}\text { K9: "Ben biraz daha sivri bir karakterim } \\
\text { diğerlerinden. Bana yapılan bir şeye karşıllk } \\
\text { verdiğimden kalabiliyorum bazen o yüzden } \\
\text { olabilir." }\end{array}$ \\
\hline Umursamaz olmak & Umursamazlık & 2 & $\begin{array}{l}\text { K15: "Umursamazlığım herhalde. Her şeyi } \\
\text { büyüten bir yapım yoktur." }\end{array}$ \\
\hline
\end{tabular}

Katılımcıların kişiden kaynaklanan nedenleri ile ilgili görüşleri incelendiğinde; 'özgüven eksik olması', 'duygusal yapılı olması', 'arkadaş canlısı olmak', 'sivri karakterli olmak', 'umursamaz olmak' gibi kavramlar üzerinde durdukları görülmüştür (Tablo 7).

Kırel (2007), bireyleri mobbinge yönelten nedenler olarak, duygusal zekadan yoksun olma, korkaklık, güvensizlik, insani ve etik değerlerden uzak olmayı göstermektedir (Kırel, 2007). Bireyi mobbinge yönelten nedenler olduğu gibi kişinin mobbinge maruz kalmasının da nedenleri vardır. Katılımcılar bu nedenleri özgüven eksik olması, duygusal yapılı olması, arkadaş canlısı olmak, sivri karakterli olmak, yaşam kaygısı olması, umursamaz olmak gibi kavramlarla açıklamışlardır. Eğer kişiler bu özelliklere sahip ise mobbinge maruz kalabilecekleri gözlemlenmiştir. Ancak, yöneticilerin alacağı; uyum, kabul, bağlılık, sadakat, güven ortamı gibi unsurlar mobbing davranışını önleyebilecektir (Kırel, 2007). 
Zapf (1999) yaptı̆̆ı araştırmada, mobbingin kişiden kaynaklanan nedenlerinin; kişilik özellikleri, sosyal beceriler ve fiziksel kusurlar olduğunu söylemiştir. Bu araştırmada da kişilik özelliğinin ve sosyal becerinin mobbing nedenlerin de etkili olabileceği görülmektedir.

2. Ana Tema'da mobbing sonuçları maddi ve manevi olmak üzere iki açıdan incelenmiştir. Verilerin analizi ile yapılan kodlamalar ile tabloda gösterilmiştir

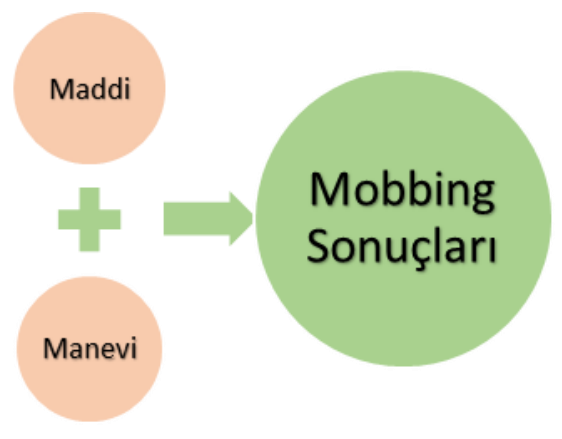

Şekil 8: Mobbing Sonuçları

Tablo 8. Mobbing maddi ve manevi sonuçları ile ilgili bulgular

\begin{tabular}{|c|c|c|c|c|c|}
\hline $\begin{array}{l}\text { Maddi sonuç } \\
\text { ile ilgili alt } \\
\text { temalar }\end{array}$ & & Örnek Katılımcı Görüşleri & $\begin{array}{l}\text { Manevi sonuç } \\
\text { ile ilgili alt } \\
\text { temalar }\end{array}$ & $\mathbf{f}$ & Örnek Katılımcı Görüşleri \\
\hline Para kaybı & 10 & $\begin{array}{l}\text { K3: "İleriye gitmediğin sürece kendini } \\
\text { gösteremezsin ve maddi olarak kazanç } \\
\text { sağlayamazsın. Bir gelir elde } \\
\text { edemezsin." } \\
\text { K13: "Profesyonel bir spor yaptığımız } \\
\text { için sezon başında masaya oturup } \\
\text { konuşulur... Sezon sonunda kaç golün } \\
\text { var, diğer tarafın kaç golü var bakılır. } \\
\text { Bu sefer maddiyattan etkilenir." }\end{array}$ & $\begin{array}{l}\text { Psikoloji } \\
\text { bozukluğu }\end{array}$ & 8 & $\begin{array}{l}\text { K13: "Manevi olarak maddiyattan } \\
\text { daha büyük. Çünkü psikolojik } \\
\text { olarak bitiriyor insanı." } \\
\text { K14: "Psikolojiyi bozar. Buna } \\
\text { maruz kalanlar ona yenik düşer ve } \\
\text { başarısı engellenir." }\end{array}$ \\
\hline Prim kaybı & 2 & $\begin{array}{l}\text { K4: "Yani o gün benim hatam } \\
\text { yüzünden gol yemişsek prim var maç } \\
\text { sonunda, onu alamazsan hem takım } \\
\text { arkadaşların hem de sen üzülürsün." }\end{array}$ & Üzülmek & 7 & $\begin{array}{l}\text { K10: "Kendini kötü hissediyorsun. } \\
\text { Önce ona yaptığın için sonrada niye } \\
\text { yaptım diye düşünüyorsun. Ailende } \\
\text { görürse bunu üzülüyorsun, onlara } \\
\text { da niye yaşattım diye." }\end{array}$ \\
\hline $\begin{array}{l}\text { Takımdan } \\
\text { atılma }\end{array}$ & 4 & $\begin{array}{l}\text { K9: “...insanın siniri bozulduğunda } \\
\text { karşısındakiyle kavga çıkarırsa olduğu } \\
\text { yerden uzaklaştırılmasına ya da } \\
\text { atılmasına sebep olabilir.” }\end{array}$ & $\begin{array}{l}\text { Özgüven } \\
\text { eksikliği }\end{array}$ & 4 & $\begin{array}{l}\text { K2: "Tabi özgüveni kırılıyor ister } \\
\text { istemez. Bir güven eksikliği } \\
\text { oluyor." } \\
\text { K3: "Bende aşırı derecede özgüven } \\
\text { eksikliği yarattı." }\end{array}$ \\
\hline $\begin{array}{l}\text { Kulüp } \\
\text { cezası }\end{array}$ & 1 & $\begin{array}{l}\text { K10: "Maddi olarak en büyüğü ceza } \\
\text { allyor kulüp..." }\end{array}$ & $\begin{array}{l}\text { Sporu } \\
\text { birakmak }\end{array}$ & 1 & $\begin{array}{l}\text { K7: "Spor hayat1 o saatten sonra } \\
\text { devam etmez." }\end{array}$ \\
\hline $\begin{array}{l}\text { Tedavi } \\
\text { masrafi }\end{array}$ & 2 & $\begin{array}{l}\text { K17: "Bir insanın ruhsal bozukluğu } \\
\text { olabilir. Çok takıyordur falan, } \\
\text { psikoloğa gider ve bir takım para } \\
\text { kaybedersin." }\end{array}$ & $\begin{array}{l}\text { Performans } \\
\text { düşüklüğ̈̈̈ }\end{array}$ & 2 & $\begin{array}{l}\text { K8: "Ĕger oyuncunun oyununa } \\
\text { göre yapıllmış bir mobbing ise bu } \\
\text { oyuncunun performansı düşer." }\end{array}$ \\
\hline $\begin{array}{l}\text { Maddi } \\
\text { kazanç }\end{array}$ & 1 & $\begin{array}{l}\text { K20: “...yapan kişi maddi olarak iyi } \\
\text { yararlanabilir. Nasıl olsa karşısındakini } \\
\text { bitirmiş } \quad \text { duygusal olarak, } \\
\text { antrenmanlara odaklanamıyor, yapan } \\
\text { kişi yükselip maaşını arttıracak.” }\end{array}$ & İlişki bağları & 1 & 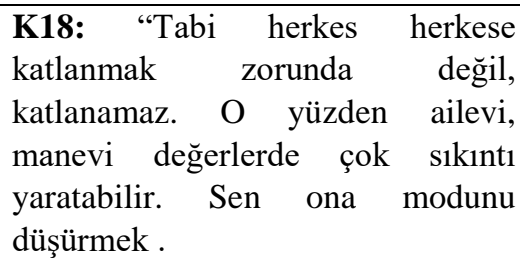 \\
\hline
\end{tabular}


Mobingin sonuçlarına yönelik olarak; katılımcıların mobbingin sonuçlarını maddi ve manevi sonuçlar olarak ikiye ayrıldığı görülmektedir.

Katılımcıların mobbingin maddi sonuçları ile ilgili görüşleri; 'para kaybı', 'prim kaybı', 'takımdan atılma', 'kulüp cezası', 'tedavi masrafi', 'maddi kazanç' olurken, katılımcıların mobbingin manevi sonuçları ile ilgili görüşleri incelendiğinde; 'psikoloji bozukluğu', 'üzülmek', ‘özgüven eksikliği’, ‘sporu bırakmak', 'performans düşüklüğü’, 'ilişki bağları' kavramları üzerinde durdukları görülmüştür (Tablo 8).

Davenport ve diğerleri (2003) mobbingin sonuçlarını psikolojik ve ekonomik maliyetler olarak ikiye ayrılmışlardır. Psikolojik maliyetler: Stres, duygusal rahatsızlıklar, fiziksel rahatsızlıklar, kazalar, sakatlıklar, tecrit edilme, ayrılık acıları, mesleki kimlik kaybı, arkadaşlıkların kaybı, intihar/ cinayet, çaresiz kalma acısı, karmaşa ve çatışmalar, ayrılık veya boşanma acısı, çocuklara etkileri, anlaşmazlıklar, hastalıklı örgüt kültürü, düşük moral, kısıtlanmış yaratıcılık, mutsuz bireyler, politik kayıtsızlıktır. Ekonomik maliyetleri ise: İlaçla ayakta tedavi, terapi masraflar, doktor faturaları, hastane faturaları, kaza masrafları, sigorta primleri, avukat ücretleri, işsizlik, kapasite altı çalıştırma, iş arama, ailenin gelir kaybı, ayrılma veya boşanma masrafları, terapi masrafları, hastalık izinlerinin artması, yüksek personel hareketinin maliyeti, düşük verim ve iş kalitesi uzmanlık kaybı, çalışanlara ödenen tazminatlar, işsizlik maliyetleri, yasal işlem dava masrafları, erken emeklilik, yükselen personel yönetim maliyetleri, sağlık masrafları, sigorta masrafları, işsizlik masrafları, kamu yardım programlarına talebin artması olarak söylemişlerdir.

Öntürk (2018), mobbing'in maddi sonuçlarını değerlendirdiğinde katılımcı görüşleri ile benzer şekilde, çalışanın psikolojik çöküntü sonrasında oluşan, ruhsal veya fiziksel rahatsızlıklarını iyileştirmek ve eski sağlı̆ına kavuşturmak amacıyla yapılan tedavi masrafları ve çalışanın işten çıkartılması sonucunda düzenli gelirinde kayıp yaşanabileceğini ifade etmektedir. Brockkötter (2016), mobbingin sonucu olarak işsizlik, tedavi masrafları ve erken emeklilik gibi sonuçları olabileceğini ileri sürmektedir. Bu görüşler katılımcı görüşleri ile örtüşmektedir. 
3. Ana Tema'da spor ortamında mobbing davranışlarının yaşanmaması için alınabilecek önlemler üzerine görüşlerden elde edilen verilerin analizi ile yapılan kodlamalar 'alt temalar' adı altında sekiz başlıkta toplanmıştır.

Tablo 9. Mobbing davranışlarının yaşanmaması için alınabilecek önlemler üzerine bulgular

\begin{tabular}{|c|c|c|c|}
\hline $\begin{array}{l}\text { Görüşme sonucu ortaya } \\
\text { çıkan kodlar }\end{array}$ & Alt temalar & $\mathbf{f}$ & Örnek Katılımcı Görüşleri \\
\hline Empati yapılmalı & Empati & 5 & $\begin{array}{l}\text { K15: "İnsanların biraz daha birbirini anlaması } \\
\text { gerekiyor. Empati kurması gerekiyor." } \\
\text { K17: "Bence herkesin empati yapması gerekiyor. } \\
\text { Çünkü empati yapmayan insan sadece kendini } \\
\text { düşünüyor ve başka insanları kırabiliyor diye } \\
\text { düşünüyorum." }\end{array}$ \\
\hline Ceza verilmeli & Ceza & 5 & $\begin{array}{l}\text { 10: "Büyük cezalar getirilebilir belki yapan kişilere. } \\
\text { Yaptığı seviyeye göre. Uzaklaştırma olabilir." } \\
\text { K18: “...Eğer cezalar daha fazla olursa azalabilir. } \\
\text { Çünkü kritik bir maçta kırmızı kart almayı kimse } \\
\text { istemeyeceği için mobbing yapmayı." }\end{array}$ \\
\hline Antrenörler dikkat etmeli & Antrenör kontrolü & 4 & $\begin{array}{l}\text { K18: "Antrenörlere çok fazla iş düşer... } \\
\text { Antrenörümüz bize kızıp, uyarabilir. O zaman karşı } \\
\text { tarafa uygulamazsın." } \\
\text { K20: "Antrenörlerin daha ilgili olması ve çaba } \\
\text { göstermesi gerekiyor. Sporcuların daha çok içinde } \\
\text { olması gerekiyor. Eğer olmazsa takıma üstünlük } \\
\text { kuruluyor." }\end{array}$ \\
\hline $\begin{array}{l}\text { Ortak çalışmalar } \\
\text { yapılmalı }\end{array}$ & Ortak çalışma & 3 & $\begin{array}{l}\text { K3: “... Ortak çalışmalar yapılmalı. Belki de takım } \\
\text { çalışması çok yapılmalı, grup çalışması." } \\
\text { K12: "... Sosyal aktivitelerde, ortak çalışmalarda } \\
\text { birleşme olabilir." }\end{array}$ \\
\hline Seminer verilmeli & Seminer & 2 & K4: "Bununla ilgili seminerler verilse çok iyi olur." \\
\hline İletişim kurulmalı & İletişim & 3 & $\begin{array}{l}\text { K2: "Genelde hocalar veya atıyorum problemli } \\
\text { oyuncular varsa onlarla konuşulabilir..." }\end{array}$ \\
\hline $\begin{array}{l}\text { Psikolojik tedavi } \\
\text { edilmeli }\end{array}$ & Tedavi & 1 & $\begin{array}{l}\text { K3: "Öncelikle bu kişileri tedavi ettirmek türk } \\
\text { sporuna, türk sporcularına, kişilere çok büyük bir } \\
\text { katk1 sağlayabilir. Bu kişilerin bulunup tedavi } \\
\text { edilmesi gerekiyor." }\end{array}$ \\
\hline $\begin{array}{l}\text { Aileler iyi bireyler } \\
\text { yetiştirmeli }\end{array}$ & İyi birey & 2 & $\begin{array}{l}\text { K5: “...iyi bir birey yetiştirmeye dikkat ederse } \\
\text { aileler." }\end{array}$ \\
\hline
\end{tabular}

Katılımcıların spor ortamında mobbing davranışlarının yaşanmaması için alınabilecek önlemler ile ilgili görüşleri değerlendirildiğinde; 'empati', 'ceza', 'antrenör kontrolü', 'ortak çalışma', 'seminer', 'İletişim', 'tedavi', ‘iyi birey’ gibi kavramlar üzerinde durdukları görülmüştür (Tablo 9).

Kırel'e (2007) göre, mobbingi engelleyebilmek için yapılması gereken ilk davranış, örgüt içerisindeki rahatsızlıkları zamanında ortaya koyabilmektir. Bu nedenle yöneticiler, mobbing davranışlarıyla ilgili erken uyarı belirtilerini izlemeli ve gereken tedbirleri almalıdırlar. Erken uyarı belirtileri dikkate alınarak, mobbingin örgüte getireceği işgücü maliyetlerini azaltacağı gibi verimliliği arttıracak, çalışanlardaki moral bozukluğunu düşürerek mobbing mağduru/mağdurları veya mobbingi gözlemleyenlerin motivasyonlarını arttıracaktır (Kırel, 2007). Örgütlerde mobbingi engellemenin bir yolu yönetici kontrolü olduğu söylenirken spor 
ortamında da bu durumun antrenör kontrolünde olabileceği söylenmiştir. Eğer antrenör takıma daha çok ilgi gösterirse, takımda olan olaylardan haberdar olursa mobbingin azalabileceği söylenmiştir. Ya da antrenörler sporcularıyla sadece sahada değil sosyal hayatlarında da ilgilenirse mobbing davranışlarını fark edebileceği bu sayede de çözüm yolu bularak mobbing davranışlarının azalacağı gözlemlenmiştir.

Mobbingin mesleki güvenlik ve sağlı bakımından önleyici tedbirlerle bağlantılı olarak, hukuki kurallar ve düzenlemeler kapsamına girmesi gerekmektedir. Mobbingin neden olduğu aşağılanmalar, psikolojik rahatsızlıklar, işten ayrılmalar, maddi kayıplar için tazminatlar ödenmesi, çalışana değer vermesi açısından önemlidir (Özkalp ve Kırel, 2016). Spor ortamında ise bu yaptırımların para cezası olabileceği, yöneticilerin vereceği cezalar olabileceği ve kişilerin mobbing yapma seviyesine göre yaptırım uygulayabilecekleri söylenmiştir.

\section{SONUÇ ve ÖNERÍLER}

Bu araştırmada takım sporcularının mobbing ile ilgili görüşlerinin incelenmesi amaçlanmıştır. Araştırma sonucunda takım sporcularının görüşleri incelendiğinde, \%70'inin mobbinge maruz kalırken, \%30 takım sporcusunun ise mobinge maruz kalmadığ1 görülmektedir. $\mathrm{Bu}$ sonuç neticesinde, araştırma grubunda yer alan kişilerin büyük çoğunluğunun spor ortamında mobbinge maruz kaldığını söylemek mümkündür.

Branş olarak, sporcuların mobbinge maruz kalma dağılımları incelendiğinde; futbol, basketbol ve voleybol branşlarında \%80 takım sporcusunun mobinge maruz kalırken, hentbol branşında ise \%60 sporcunun mobbinge maruz kaldığı sonucuna ulaşılmıştır. Bu sonuç neticesinde, futbol, basketbol ve voleybol branşında sporculara uygulanan mobbingin azaltılmasına yönelik çalışmalar yapılması önerilmektedir.

Takım sporcularına spor ortamında kimlerin mobinge maruz kaldığı şeklinde yöneltilen soruya katılımcıların çoğunluğunun; 'sessiz oyuncu' 'ların daha fazla mobbinge maruz kaldığ yönünde görüş bildirdikleri görülmüştür. Bu bağlamda, kişi sessiz ve pasif olduğu takdirde mobbinge uğrama ihtimalinin yüksek olduğunu söylemek mümkündür. Bununla birlikte, küçük yaşta bir oyuncuysa büyük yaştaki oyuncu tarafından mobbinge maruz kalacağı da katılımcı görüşleri neticesinde elde edilen bulgulardandır. Öntük’ e göre, takım sporlarında bu durumun bir norm haline geldiği ve yaşı büyük olan sporcuların küçük yaştaki sporculara istediklerini yaptırdıklarını ifade etmektedir. Yine takıma yeni gelen sporculara, eski sporcuların çaylak gibi lakaplar takılmasının da mobbing olarak kabul edildiği ifade edilmektedir. Ayrıca, özellikle literatür olarak da desteklenen performansı yüksek sporculara performanslarını düşürmek için de takım arkadaşları tarafından mobbing yapıldığı görülmektedir. Literatür olarak da iş ortamlarında genellikle başarılı ve performansı yüksek, terfi alma ihtimali olan kişilerin çalışma arkadaşları tarafindan potansiyel bir risk olarak algılandığı performansını düşürmek için mobbing uygulandığı bilinmektedir (Yıldız, 2015). Bunula birlikte; duygusal, performansı düşük, takım arkadaşları tarafından egolu olarak kabul edilen oyuncuların da mobbinge maruz kaldığı katılımcı görüşleri neticesinde ortaya çıkmaktadır. Aynı zamanda, yine araştırma neticesinde sadece oyuncuların değil aynı 
zamanda hakemlerin ve antrenörlerin de mobbinge maruz kaldığı yine katılımcı görüşleri neticesinde elde edilen bulgulardandır. Katılımcı görüşleri ve alan yazında yapılan çalışmalar değerlendirildiğinde, spor ortamında çok farklı açılardan kişilerin mobbinge maruz kaldığını söylemek mümkündür. Bu durumun iyileştirilebilmesi için, spor ortamında takım içinde ve dışında rekabet unsurunun olduğu ancak rekabet ederken fair-play anlayışından uzaklaşılmaması gerektiği vurgulanmalıdır. Ayrıca, özellikle takım sporlarında bireysel amaçların üstünde takım amaçlarının olduğu hatırlatılmalı ve sporcuların, antrenörlerin ve yöneticilerin bu amaca yönlendirilmesinin sağlanması gerektiği önerilmektedir. Son olarak, takım içerisinde sporcuların birbirlerine yapmış oldukları mobbingin azaltılması için takımdaşıık kavramını geliştirici çalışmalar yapılması önerilmektedir.

Katılımcılara, spor ortamında kimler mobing yapar sorusu sorulduğunda; katılımcıların çoğunlukla, baskıcı davranmak, saldırgan olmak, aşağılayıcı sözler söylemek ve aşağılayıcı hareketler yapmak gibi karakteristik özelliğe sahip kişilerin mobbing yaptığı yönünde görüş bildirdikleri görülmüştür. Ayrıca, tecrübeli oyuncuların, yeni gelen küçük yaştaki oyuncular üzerinde hakimiyet kurmak istemesinden dolayı mobbing yaptıkları da katılımcı görüşleri neticesinde elde edilen bulgulardandır. Katılımcılar, mobbing davranışlarının, takım oyuncularının birbirleri arasında olabileceği gibi rakip takım oyuncularının maç esnasında veya öncesinde çeşitli aşağılayıcı sözler söyleyerek veya hareketlerde bulunarak da mobbing yaptıklarını ifade etmişlerdir. Ayrıca, sporcular takım kaptanı, takım arkadaşı, takımın zayıfları ve psikolojik sorunlu kişilerin ve sporcular dışında antrenör, kulüp başkanı ve taraftarların de spor ortamında mobbing yaptıkları yönünde görüş bildirmişlerdir.

Katılımcıların, sporcular açısından hangi davranışların mobbing olarak kabul edildiği yönündeki görüşleri incelendiğinde; en çok "hakaret" kavramı üzerinde durdukları görülmüştür. Takım içerisindeki kötü konuşma, alay konusu olacak bir şaka veya kişiyi küçük düşürecek her türlü kötü davranış mobbing olarak sayılabilmektedir. Katılımcıların üzerinde durduğu başka bir kavram ise kışkırtmadır. Özellikle maç esnasında, kişiyi kızdıracak, moralini bozacak ve onu kışkırtacak her türlü davranışı da mobbing olarak değerlendirmektedirler. Bununla birlikte, katılımcılar, sporcunun takım içerisinde başarılı olmasına rağmen takdir edilmemesini de mobbing davranışı olarak kabul etmektedirler. Son olarak fiziksel şiddet de katılımcılar tarafından mobbing davranışı olarak görülmektedir. $\mathrm{Bu}$ bulgular 1şığında, takımlar içerisinde iletişimin geliştirilmesi gerektiği önerilebilmektedir. Mobbing davranışlarını aza indirmek için takım içerisindeki ilişkiler geliştirilebilir. Ayrıca, takım oyuncularının birlikte takım olarak yapabilecekleri antremanlar planlanarak ya da birlikte zaman geçirebileceği etkinlikler düzenlenerek birbirlerini yakından tanımaları için firsatlar sağlanabilir buna bağlı olarak da kişilerin birbiriyle olan ilişkileri geliştirilebilir.

Araştırmada takım sporcularının mobbing ile ilgili görüşleri; mobbinge maruz kalmanın nedenleri, mobingin sonuçları ve mobbing davranışlarının yaşanmaması için alınabilecek önlemler olmak üzere 3 ana tema altında toplanmıştır. Mobinge maruz kalma temaları; örgütten kaynaklı nedenler, sosyal gruptan kaynaklı nedenler ve kişiden kaynaklı nedenler olmak üzere 3 ayrı alt temada incelenmiştir. Örgütten kaynaklanan mobbing nedenleri ile ilgili görüşler incelendiğinde, adalet, rekabet, kötü oynamak, kötü performans, uygun olmak, sevilmemek, kıskançlık, baskı, bilinçsizlik gibi kavramlar üzerinde durdukları görülmüştür. 
Takım içerisindeki oyuncular arasında rekabet yaşanıyorsa, sporcunun kötü oynaması isteniliyorsa, kişi sevilmiyorsa, kıskanılıyorsa, onu düşürmek için her türlü mobbing davranışı yapılacağı katılımcı görüşleri neticesinde görülmektedir. Sosyal gruptan kaynaklanan mobbing nedenleri ile ilgili görüşler değerlendirildiğinde; 'gruplaşma', 'liderlik', 'moral bozmak', 'görünüş', 'fikir ayrılığı', 'kişisel amaçlar', 'eğlence' gibi kavramlar üzerinde durdukları görülmüştür. Sosyal grup, örgüte kıyasla informal bir gruptur. $\mathrm{Bu}$ yüzden belli kuralları yoktur. Arkadaş çevresinde olacak fikir ayrılıkları ve bazı anlaşmazlıkların mobbinge maruz bırakabileceği düşünülmektedir. Takım sporcularının kişiden kaynaklanan mobbing nedenleri ile ilgili görüşleri incelendiğinde; en çok özgüven kavramı üzerinde durdukları görülmüştür. Kişinin içine kapanık olması, yapabilecek hareketleri özgüveni olmadığı için yapamaması, kendine güvenen kişiler tarafından mobbinge maruz bırakılacağı düşünülmektedir. Katılımcıların, duygusal yapılı olmak, arkadaş canlısı olmak, sivri karakterli olmak ve umursamaz olmak gibi kavramlar üzerinde de durdukları görülmüştür.

Mobingin sonuçları ile ilgili görüşler incelendiğinde; katılımcıların mobbingin sonuçlarını maddi ve manevi sonuçlar olarak ikiye ayrıldı̆̆ görülmektedir. Mobbingin maddi sonuçları değerlendirildiğinde; en çok para kaybı kavramı üzerinde durdukları görülmüştür. Sporcular, kulüplerde oynadıklarında belli bir ücret almaktadırlar. Mobbing sonucunda kişinin performası düştüğünde veya sözleşme imzalayamadıklarında para kaybı olur. Mobbingin kişide psikolojik sorunlara yol açabileceği, bununda tedavi masraflarını doğurabileceği düşünülmektedir. Aynı zamanda prim kaybı, takımdan atılma ve kulüp cezası olacağı düşünülmektedir. Maddi sonuçlarında sadece kötü sonuçlardan söz edilmemiştir. Mobbing uygulayanın maddi kazanç sağlayacağı düşünülmektedir. Karşısındaki kişilere mobbing uygulayarak düşürebilir ve bu da kendisinin yükselmesini sağlayacağ 1 düşünülmektedir. Katılımcıların mobbingin manevi sonuçları ile ilgili görüşleri incelendiğinde; 'psikoloji bozukluğu', 'üzülmek', 'özgüven eksikliği', 'sporu bırakmak', 'performans düşüklüğü', 'ilişki bağları' kavramları üzerinde durdukları görülmüş̧ür. Manevi sonuçların, maddi sonuçlara göre kişiyi daha çok etkilediği ve iz bıraktığı düşünülmektedir.

Katılımcıların mobbing davranışlarının yaşanmaması için alınabilecek önlemler ile ilgili görüşleri incelendiğinde; en çok empati ve ceza kavramı üzerinde durdukları görülmüsstür. Ayrıca katılımcılar, antrenör kontrolü, ortak çalışma, seminer, iletişim, tedavi ve iyi birey gibi kavramların da spor ortamında mobbingi azaltabilecek önlemler olduğunu ifade etmişlerdir. Spor ortamında başta kulüp yöneticileri olmak üzere, gerekli tedbirler alındığ takdirde mobbing davranışlarının azalacağı ve buna bağlı olarak sporcuların ve antrenörlerinin verimliliklerinin artarak istenilen başarılara ulaşılabileceği düşünülmektedir.

Yayın Etiği: $\mathrm{Bu}$ çalışmanın hazırlanma ve yazım sürecinde "Yükseköğretim Kurumları Bilimsel Araştırma ve Yayın Etiği Yönergesi” kapsamında bilimsel, etik ve alıntı kurallarına uyulmuş olup; toplanan veriler üzerinde herhangi bir tahrifat yapılmamış ve bu çalışma herhangi başka bir akademik yayın ortamına değerlendirme için gönderilmemiştir. 


\section{KAYNAKLAR}

Alparslan, A. M., ve Tunç, H. (2009). Mobbing olgusu ve mobbing davranışlarında duygusal zeka etkisi. Süleyman Demirel Üniversitesi Vizyoner Dergisi, 1(1), 146-159.

Brockkötter, F. (2016). Mobbing im sport. https://prezi.com/c_om2nqepolj/mobbing-im-sport/.

Çiftçi, G. E., Öneren, M., ve Önem, A. (2013). Çalışanlarda psikolojik yıldırma ve endişe düzeyi. "Işs, Güç" Endüstri İlişkileri ve Insan Kaynakları Dergisi, 15(2), 63-81.

Çobanoğlu, Ş. (2005). Mobbing-İşyerinde duygusal saldırı ve mücadele yöntemleri. İstanbul: Timaş Yayınları.

Davenport, N., Schwartz, R., \& Elliott, G. (2003). Mobbing iş yerinde duygusal taciz. Çeviren; Önertoy O. İstanbul: Sistem Yayıncılık ve Mat. San. Tic. A.Ş.

Davenport, N., Schwartzve, R., \& G.P.Elliott. (1999). Mobbing: Emotional abuse in the American workplace. Ames: Civil Society Publishing.

Filiz, D., Kemeç, G., ve Ataşoğlu, İ. (2019). Beden Eğitimi ve Spor Yüksekokulu öğrencilerinin mobbing algılama düzeyleri. Uluslararas1 Bilim ve Eğitim Kongresi 2019 (UBEK2019).

Gül, H. (2009). İş sağlı̆̆ında önemli bir psikososyal risk: Mobbing-psikolojik yıldırma. TAF Preventive Medicine Bulletin, 8(6), 515-520.

Hacicaferoğlu, S., ve Çoban, B. (2011). Gençlik ve Spor İl Müdürlüğü personelinin çalışma ortamında maruz kaldığı yıldırma davranışlarının incelenmesi. Spor ve Performans Araştırmaları Dergisi, 2(2), 38-50.

İlhan, Ü. (2010). İşyerinde psikolojik tacizin (mobbing) tarihsel arka planı ve türk hukuk sisteminde yeri. Ege Akademik Bakış, 10(4), 1175 - 1186.

İslamoğlu, A. H., ve Alnıaçık, Ü. (2016). Sosyal bilimlerde araştırma yöntemleri. İstanbul: Beta Yayıncılık.

İyem, C. (2007). Futbolda mobbing: Sakaryaspor A.Ş. örneği. XV. Ulusal Yönetim ve Organizasyon Kongresi Bildiriler Kitabı, Sakarya, 919-938.

Karık, T. ve Yıldız, S.M. (2015). Mobbing davranışlarının kadın basketbolcuların tükenmişliği üzerine etkisi. Uluslararası İnsan Bilimleri Dergisi, 12(2), 430-442.

Kırel, Ç. (2007). Örgütlerde mobbing yönetiminde destekleyici ve risk azaltıcı öneriler. Anadolu Ünivesitesi Sosyal Bilimler Dergisi, 7(2), 317-334.

Leymann, H. (1996). The content and development of mobbing at work. European Journal of Work and Organizational Psychology, 5(2), 165-184.

Lazarević, S., Krstić, A., \& Sobek, M. (2015). Perceptıon of athletes regarding mobbing in sports clubs. SPORT-Science\&Practice, 5(1), 5-17.

Öntürk, Y. (2018). Spor ortamında mobbing. Ankara: Gece Kitaplığı Yayınevi.

Özkalp, E., ve Kırel, Ç. (2016). Örgütsel davranış. Bursa: Ekin Basım Yayın Dağıtım.

Salman, M. N., ve Yalçındağ, S. (2017). Sporda mobbing uygulamaları ve sporcuların mobbing algılama düzeylerinin tespiti. Kastamonu Ĕ̈itim Dergisi , 25(6), 2479-2490. 
Strauss, A., \& Corbin, J. (1990). Basics of qualitative research techniques and procedures for developing grounded theory. London: Sage Publications.

Tınaz, P. (2008). İşyerinde psikolojik yıldırma (mobbing). İstanbul. Beta Yayınları.

Tutar, H. (2004). İşyerinde psikolojik şiddet sarmalı: nedenleri ve sonuçları. Yönetim Bilimleri Dergisi, 2(2), 101-128.

Üstün, E., ve Pulur, A. (2016). Spor eğitimi veren yüksek öğretim kurumlarındaki öğretim elemanlarının mobbing alg1 düzeyleri. İönü Üniversitesi Beden Eğitimi ve Spor Bilimleri Dergisi, 3(2), 1-10.

Yıldırım, A., ve Şimşek, H. (2011). Sosyal bilimlerde nitel araştırma yöntemleri. Ankara: Seçkin Yayıncılık.

Yıldız, B. S., Kepoğlu, A., ve Yıldız, S.M. (2018). Mobbing davranışlarının amatör futbolcuların tükenmişliğine etkisi. CB̈̈ Beden Eğitimi ve Spor Bilimleri Dergisi, 13(2), 231-246.

Y1ld1z, S.M. (2015). The relationship between bullying and burnout: An empirical investigation of Turkish professional football players. Sport, Business and Management: An International Journal, 5(1), 6-20.

Zapf, D. (1999). Organisational, work grouprelated and personal causes ofmobbing/bullying at work. International Journal of Manpower, 20(1/2), 70-85.

Bu eser Creative Commons Atıf-GayriTicari 4.0 Uluslararası Lisansı ile lisanslanmıştır. 